\title{
Micronodular thymic neoplasms: case series and literature review with emphasis on the spectrum of differentiation
}

\author{
Wadad S Mneimneh ${ }^{1}$, Yesim Gökmen-Polar², Kenneth A Kesler ${ }^{3}$, Patrick J Loehrer Sr ${ }^{4}$ and \\ Sunil Badve ${ }^{1}$ \\ ${ }^{1}$ Department of Pathology and Laboratory Medicine, Indiana University School of Medicine, Indianapolis, IN, \\ USA; ${ }^{2}$ Department of Pathology and Laboratory Medicine, Indiana University School of Medicine, \\ Indianapolis, IN, USA; ${ }^{3}$ Department of Surgery, Indiana University School of Medicine, Indianapolis, IN, USA \\ and ${ }^{4}$ Department of Medicine, Indiana University Simon Cancer Center, Indiana University School of \\ Medicine, Indianapolis, IN, USA
}

\begin{abstract}
We report nine cases of micronodular thymoma with lymphoid B-cell hyperplasia and one case of micronodular thymic carcinoma with lymphoid hyperplasia from our institution. For a better understanding of these rare tumors, clinical records, and histological features of these cases were reviewed, with detailed review of additional 64 literature cases of micronodular thymic neoplasms. The joint analysis identified 64 cases of micronodular thymoma with lymphoid B-cell hyperplasia and 9 cases of micronodular thymic carcinoma with lymphoid hyperplasia. Both groups revealed slight male predilection, with male:female ratio of 1.3:1 and 5:4, and occurred at $>40$ years of age, with a mean of $64(41-83)$ and $62(42-78)$ years, respectively. Myasthenia gravis was noted in $3 / 64(5 \%)$ and $1 / 9(11 \%)$ patients, respectively. Other systemic, disimmune, or hematologic disorders were noted in $6 / 64(9 \%)$ and $1 / 9(11 \%)$ patients, respectively. Components of conventional thymoma were reported in 11/64 (17\%) micronodular thymomas with lymphoid B-cell hyperplasia, with transitional morphology between the two components in most of them. Cellular morphology was predominantly spindle in micronodular thymoma with lymphoid B-cell hyperplasia when specified (30/43), and epithelioid in micronodular thymic carcinoma with lymphoid hyperplasia (6/9), and cytological atypia was more encountered in the latter. Dedifferentiation/transformation from micronodular thymoma with lymphoid B-cell hyperplasia to micronodular thymic carcinoma with lymphoid hyperplasia seems to occur in a small subset of cases. Three cases of micronodular thymomas with lymphoid B-cell hyperplasia were described with co-existent low-grade B-cell lymphomas. Follow-up data were available for $\mathbf{3 0}$ micronodular thymomas with lymphoid B-cell hyperplasia and 6 micronodular thymic carcinomas with lymphoid hyperplasia, with a mean of $47(0.2-180)$ months and 23 (3-39) months, respectively. Patients were alive without disease, except for five micronodular thymoma with lymphoid B-cell hyperplasia patients (dead from unrelated causes), and one micronodular thymic carcinoma with lymphoid hyperplasia patient (dead of disease).
\end{abstract}

Modern Pathology (2015) 28, 1415-1427; doi:10.1038/modpathol.2015.104; published online 11 September 2015

Thymic epithelial tumors tend to be associated with lymphocytic infiltration. This infiltrate is typically composed of $\mathrm{T}$ cells that show varying degree of 'maturation'. A conspicuous B-cell lymphoid population is rarely seen in thymomas, and lymphoid aggregates with germinal centers are only seen in a minority of thymic neoplasms. ${ }^{1,2}$ This minor group

Correspondence: Dr WS Mneimneh, MD, Department of Laboratory Medicine and Pathology, Mayo Clinic, Hi-11, 200 First Street SW, Rochester, MN 55905, USA.

E-mail: wadadmneimneh@yahoo.com

Received 29 June 2015; revised 9 July 2015; accepted 10 July 2015; published online 11 September 2015 of tumors is herein referred to as micronodular thymic neoplasms with follicular lymphoid hyperplasia, and includes micronodular thymomas with lymphoid B-cell hyperplasia, and micronodular carcinomas with lymphoid hyperplasia. In addition to the abundant lymphoid stroma with prominent follicular lymphoid hyperplasia,, ${ }^{1,2}$ these tumors are particularly characterized by a micronodular arrangement of the epithelial tumor cells as their name implies.

Micronodular thymomas with lymphoid B-cell hyperplasia were first described in 1999 in a series of 18 patients. ${ }^{1}$ When first reported, the epithelial 
cells were described as bland spindle 'type A medullary' cells. Subsequent reports have documented variations in the clinical and pathologic manifestations of this group of thymic tumors, including the presence of polygonal cell. ${ }^{3-9}$ Micronodular thymic carcinoma with lymphoid hyperplasia was more recently described as the malignant counterpart of micronodular thymoma with lymphoid B-cell hyperplasia. ${ }^{2}$ It has clinical and demographic presentations similar to those of micronodular thymoma with lymphoid B-cell hyperplasia. Cases of micronodular thymic carcinoma with lymphoid hyperplasia ${ }^{1,2}$ display a benign micronodular component as well as a carcinomatous component. These two constituents are most often well demarcated from each other; only rarely a transition between these two is noted (in one case of the original series $^{2}$ ). The benign micronodular component is morphologically similar to micronodular thymoma with lymphoid B-cell hyperplasia, ${ }^{1,2}$ but the micronodules often coalesce to form more solid and irregular areas, and exhibit variable admixture of spindle and polygonal cells with mild to moderate atypia rather than solely bland spindle cells. ${ }^{2,3}$ The malignant component consists of squamous cell carcinoma, spindle cell carcinoma and/or lymphoepithelioma-like carcinoma. ${ }^{1-3}$

The main feature of distinction between micronodular thymoma with lymphoid B-cell hyperplasia and micronodular thymic carcinoma with lymphoid hyperplasia is the presence of areas of 'frankly' malignant component in micronodular thymic carcinoma with lymphoid hyperplasia. ${ }^{2}$ Nevertheless, the concept of morphologic spectrum of micronodular thymic proliferations, varying from benign micronodular thymoma with lymphoid B-cell hyperplasia, to micronodular thymic carcinoma with lymphoid hyperplasia, was first proposed in 2000 by Tateyama et al. ${ }^{3}$ The 11 cases in this series were divided based on morphology and immunohistochemistry, into four groups, with the group 1 showing bland spindle epithelial cells; group 2, an admixture of spindle and polygonal epithelial cells; group 3, predominance of polygonal epithelial cells with mild to moderate cytological atypia, and group 4 representing overt carcinoma (lymphoepitheliomalike carcinoma component in two cases, in addition to keratinizing squamous cell carcinoma in one of them). Beside the spindle or epithelioid morphology of the epithelial cells, Tateyama et $a l^{3}$ noted several additional features that gradually increased as the tumor morphology progressed from group 1 to group 4. These features included the presence of thick fibrous septa, enlargement of the size of micronodules to form a more irregular growth pattern, cytological atypia, mitotic count, and overexpression of bcl2 and p53. Mitotic activity was low (up to 2 per 10 high power fields) in the cases of micronodular thymoma with lymphoid B-cell hyperplasia that showed mild atypical features (groups 2 and 3 ), and high (up to 6 per 10 high power fields) in the two cases of carcinoma. Generally, mitotic rate in micronodular thymic carcinoma with lymphoid hyperplasia reported in the literature varies between 5 and 16 per 10 high power fields. ${ }^{2,3}$

Micronodular thymomas with lymphoid B-cell hyperplasia are rare and account for only less than $5 \%$ of all thymomas. ${ }^{2,4}$ They usually present as a variably cystic mass lesion that is well encapsulated or minimally invasive (Masaoka stage-1 or stage-2 disease) and have a favorable outcome. ${ }^{1,3-9}$ Micronodular thymic carcinomas with lymphoid hyperplasia are even rarer. The outcome of micronodular thymic carcinoma with lymphoid hyperplasia patients appears to be overall similar to those with more conventional types of thymic carcinoma. It must be noted that this is based on a limited number of cases with short follow-up periods. ${ }^{2}$

In this study, we report the histopathological features of micronodular thymic neoplasms with follicular lymphoid hyperplasia diagnosed in our institution. An exhaustive review of the literature was also performed for a better demographic and morphological characterization of these tumors.

\section{Materials and methods}

Surgical pathology files at our institution were searched for thymic tumors specimens over the past 16 years (1987-2014), including in-house cases and outside cases received as consults. All cases diagnosed as micronodular thymoma with lymphoid B-cell hyperplasia or containing a component of micronodular thymoma with lymphoid B-cell hyperplasia were retrieved. Medical records were reviewed to check for the patients presentation, clinical history, radiologic findings, modality of treatment, and follow-up. Hematoxylin and eosin-stained sections were reviewed in each case by two pathologists, along with the pathology reports and case histories.

When available, tumor dimension was taken from the gross description or radiological studies. The following features were assessed: size of tumor, extent of the solid and cystic components, the presence and extent of invasion, the presence or absence of necrosis, morphology of epithelial cells (spindle, epithelioid, or mixed, with predominant type being noted), number of mitosis per 10 high power fields in the highest proliferative areas, the presence or absence of adjacent conventional type thymoma component, the presence or absence of adjacent carcinoma component, and the presence and appearance of identifiable adjacent residual non-tumoral thymic tissue.

\section{Results}

Micronodular Thymic Tumors with Follicular Hyperplasia from This Study

We identified 10 cases of micronodular thymic neoplasms with follicular lymphoid hyperplasia, 
including four male and six female patients with an age range from 41 to 83 years.

Nine of our cases were micronodular thymoma with lymphoid B-cell hyperplasia (Table 1, Figure 1) including four male and five female patients, from 51 to 83 years of age. Of these, one patient presented with concurrent lung adenocarcinoma. Systemic presentations were seen in four patients including hypothyroidism; incidental MGUS IgA lambda that persisted after surgery and lytic lesion of skull; Protein S deficiency and vision impairment (without myasthenia gravis or hypothyroidism); and ulcerative colitis. Among our cases of micronodular thymoma with lymphoid B-cell hyperplasia, three cases were spindle cell predominant and three were epithelioid cell predominant. Most of the cases showed micronodular component that gradually coalesced in more irregular sheets or cords of epithelial cells. Six of the cases at least focally had thick fibrous bands. Among the three cases that lacked thick fibrous bands, two showed mixture of spindle and epithelioid cells and one had spindle cell predominance. None of the micronodular thymoma with lymphoid B-cell hyperplasia cases showed necrosis. Mitoses varied between 1 and 11 per 10 high power fields. One of the cases of micronodular thymomas with lymphoid B-cell hyperplasia was stage 3 , six were stage 2 , and two were stage 1. Increased stage did not appear to be related to the mitotic count or epithelial cell morphology.

Conventional thymoma component was seen in seven of the micronodular thymoma with lymphoid B-cell hyperplasia cases, often with transition between the micronodular and conventional components. The latter included types A spindle, A epithelioid, $A B$, and B2. One case showed (in addition to an $\mathrm{AB}$ thymoma component) a nodular sclerosed area reminiscent of an 'ancient' sclerosing thymoma component. The lymphoid follicles appeared regressed and somewhat atrophic in three cases of micronodular thymoma with lymphoid B-cell hyperplasia, but without classic Castleman disease-like appearance. The adjacent residual non-tumoral thymic tissue was atrophic in all nine cases, with few lymphoid follicles in one case.

The only case of micronodular thymic carcinoma with lymphoid hyperplasia (Figure 2) identified in our series occurred in a 75-year-old female with history of myasthenia gravis and previous exposure to radiation (the patient worked in radiology department in her home-country without appropriate protective measures). The tumor was solid. The carcinomatous component consisted of a spindle cell (sarcomatoid) carcinoma and lymphoepitheliomalike carcinoma, showing a transitional progression toward the lower grade micronodular component. The epithelial cells in the micronodular areas were predominantly epithelioid. The tumor was focally lobulated with thick hyalinized fibrous bands. No invasion was demonstrated. Mitoses varied between 3 (in low-grade morphology) and 8 (in carcinoma) per 10 high power fields, and necrosis was present as comedo-like type in the lymphoepithelioma-like carcinomatous component. The lymphoid follicles were enlarged with an appearance reminiscent of progressive transformation of germinal center. The adjacent residual non-tumoral thymic tissue was atrophic, but revealed some lymphoid follicles.

All of our cases of micronodular thymic neoplasms with follicular lymphoid hyperplasia were treated surgically at variable institutions across the country. In addition, one of the patients received chemotherapy for his concurrent lung adenocarcinoma, and the patient with micronodular thymic carcinoma with lymphoid hyperplasia received adjuvant radiation therapy.

\section{Micronodular Thymic Neoplasms with Follicular Lymphoid Hyperplasia in Literature}

Table 2 summarizes the clinical and pathological characteristics of micronodular thymic neoplasms with follicular lymphoid hyperplasia cases previously reported in the literature. Eight cases of micronodular thymic carcinoma with lymphoid hyperplasia were identified, ${ }^{2}$ as well as 55 cases of micronodular thymoma with lymphoid B-cell hyperplasia, ${ }^{1,3}$ three of which exhibiting a lymphomatous component (two marginal zone lymphoma and one follicular B-cell lymphoma WHO grade 1-2). Myasthenia gravis was noted in three cases of micronodular thymoma with lymphoid B-cell hyperplasia. Other systemic, disimmune, or hematologic disorders were noted in both categories, including two patients with micronodular thymoma with lymphoid B-cell hyperplasia (hypogammaglobulinemia and splenomegaly with anemia of undetermined etiology), and two cases of micronodular thymic carcinoma with lymphoid hyperplasia (Sjogren disease with hypogammaglobulinemia and cavitary tuberculosis of the lung).

An association with various malignancies was noted only in the micronodular thymoma with lymphoid B-cell hyperplasia category: four patients had a history of carcinomas (of the rectum, esophagus, breast, and uterine cervix, respectively) and one had a history of melanoma.

Coexistence of conventional thymoma component was reported only in four cases of micronodular thymoma with lymphoid B-cell hyperplasia. It consisted of type A (3 cases) or B2 (1 case), with a transition between the micronodular thymoma with lymphoid B-cell hyperplasia and the conventional thymoma component noted in three of them.

The appearance of the adjacent thymic tissue was mentioned in eight cases of micronodular thymoma with lymphoid B-cell hyperplasia, one of these showed lymphoid follicles (patient without myasthenia gravis) and seven were atrophic, two of which showed lymphoid follicles. The appearance of the adjacent thymic tissue was mentioned in 
Table 1 Cases of micronodular thymomas with lymphoid B-cell hyperplasia from the current series

\begin{tabular}{|c|c|c|c|c|c|c|c|c|c|c|c|c|c|c|c|c|}
\hline Case \# & Age & Sex & $\begin{array}{l}\text { Clinical } \\
\text { history }\end{array}$ & Size $(\mathrm{cm})$ & Gross & Stage & Therapy & Follow-up & $\begin{array}{l}\text { Follow- } \\
\text { up } \\
\text { duration }\end{array}$ & $\begin{array}{l}\text { Epithelial } \\
\text { cells }\end{array}$ & Atypia & $\begin{array}{l}\text { Mitotic } \\
\text { count }^{\mathrm{a}}\end{array}$ & $\begin{array}{l}\text { Fibrous } \\
\text { bands }\end{array}$ & $\begin{array}{l}\text { Lymphoid } \\
\text { tissue } \\
\text { specificity }\end{array}$ & $\begin{array}{l}\text { Residual } \\
\text { thymus }\end{array}$ & $\begin{array}{l}\text { Conventional } \\
\text { thymomal } \\
\text { transition }\end{array}$ \\
\hline 1 & 79 & $\mathrm{~F}$ & NA & NS & $S \& C$ & 1 & $\mathrm{R}$ & NA & NA & $\begin{array}{l}\text { Sp, rare } \\
\text { Ep }\end{array}$ & No & 2 to 8 & No & $\begin{array}{l}\text { Some } \\
\text { atrophic }\end{array}$ & Atrophic & $\begin{array}{l}1 \mathrm{~cm} \text { type } \mathrm{A} \\
\text { thymoma/Yes }\end{array}$ \\
\hline 2 & 83 & $\mathrm{M}$ & NA & $\begin{array}{c}8.5 \times 7 \times 4 \\
\text { MNT: } 30 \%\end{array}$ & $\begin{array}{l}\text { S, rare } \\
\text { micro-c }\end{array}$ & 1 & $\mathrm{R}$ & NA & $\mathrm{NA}$ & $\mathrm{Ep}>\mathrm{Sp}$ & Mild & 3 & Yes & NA & $\begin{array}{l}\text { Atrophic } \\
\text { with LF }\end{array}$ & $\mathrm{AB} \& \mathrm{~B} 2 / \mathrm{Yes}$ \\
\hline 3 & 70 & M & NA & 5.9 & $\mathrm{~S}$ & $2 a$ & $\mathrm{R}$ & NA & NA & $\mathrm{Ep}$ & Mild & 11 & Yes & NA & Atrophic & $\begin{array}{l}\text { Epithelioid } \\
\text { A/Yes }\end{array}$ \\
\hline 4 & 64 & $\mathrm{~F}$ & $\begin{array}{l}\text { hThyr, } \\
\text { osteop, } \\
\text { right facial } \\
\text { paralysis }\end{array}$ & $6 \times 6 \times 6$ & S & 3 & $\mathrm{R}$ & NA & NA & $\mathrm{Sp}$ & No & 1 & Focal & NA & Atrophic & $\begin{array}{l}0.5 \mathrm{~cm} \text { nodules } \\
\text { of cellular } \\
\mathrm{A} / Y e s\end{array}$ \\
\hline 5 & 61 & $\mathrm{~F}$ & NA & $3 \times 2.5 \times 2$ & $\begin{array}{l}\text { S, rare } \\
\text { micro-C }\end{array}$ & $2 \mathrm{a}$ & $\mathrm{R}$ & NA & NA & Sp \& Ep & No & 2 & Yes & NA & Atrophic & $\begin{array}{l}\text { AB/Yes \& } \\
\text { Sclerosed } \\
\text { ancient } \\
\text { thymoma }\end{array}$ \\
\hline 6 & 73 & $\mathrm{~F}$ & $\begin{array}{l}\text { MGUS IgA } \\
\text { lambda } \\
\text { persisted } \\
\text { after R, } \\
\text { lytic lesion } \\
\text { of skull }\end{array}$ & $\begin{array}{l}4.5 \times 4.4 \times 3 \\
\text { MNT: } 40 \%\end{array}$ & $\begin{array}{l}\text { S, rare } \\
\text { micro-C }\end{array}$ & $2 a$ & $\mathrm{R}$ & A & $6 y$ & Sp \& Ep & No & 2 & No & NA & Atrophic & $\mathrm{AB}$ \\
\hline 7 & 63 & M & Lung Adeno & $5.5 \times 4 \times 1.5$ & S, rare C & $2 \mathrm{a}$ & $\begin{array}{l}\text { R Chem } \\
\text { for lung } \\
\text { Ca }\end{array}$ & A & $3 y$ & $\mathrm{Ep}>\mathrm{Sp}$ & Mild & 5 & Focal & NA & Atrophic & $\mathrm{A} 2$ \\
\hline 8 & 51 & $\mathrm{M}$ & $\begin{array}{l}\text { HTN, DM2, } \\
\text { Prot S } \\
\text { deficit, } \\
\text { impaired } \\
\text { vision }\end{array}$ & $4.8 \times 2.7$ & $S \& C$ & $2 a$ & $\mathrm{R}$ & A & $\begin{array}{l}\text { Recent } \\
\text { case }\end{array}$ & Sp \& Ep & Mild & 5 & No & $\begin{array}{l}\text { Some } \\
\text { atrophic }\end{array}$ & Atrophic & No \\
\hline 9 & 53 & $\mathrm{~F}$ & UC & $3 \times 2.8 \times 1.5$ & $\mathrm{~S}$, rare $\mathrm{C}$ & $2 a$ & $\mathrm{R}$ & A & $3 y$ & $\begin{array}{l}\text { Sp, } \\
\text { rare Ep }\end{array}$ & No & 1 & Focal & $\begin{array}{l}\text { Some } \\
\text { atrophic }\end{array}$ & Atrophic & No \\
\hline
\end{tabular}

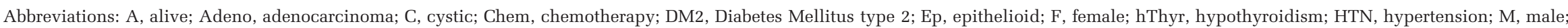

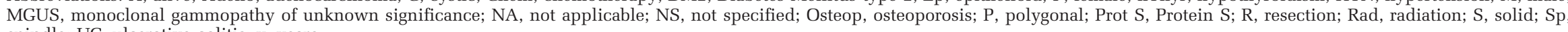

spindle; UC, ulcerative colitis; y, years.
${ }^{a}$ Mitotic figures: Count per 10 high power fields. 

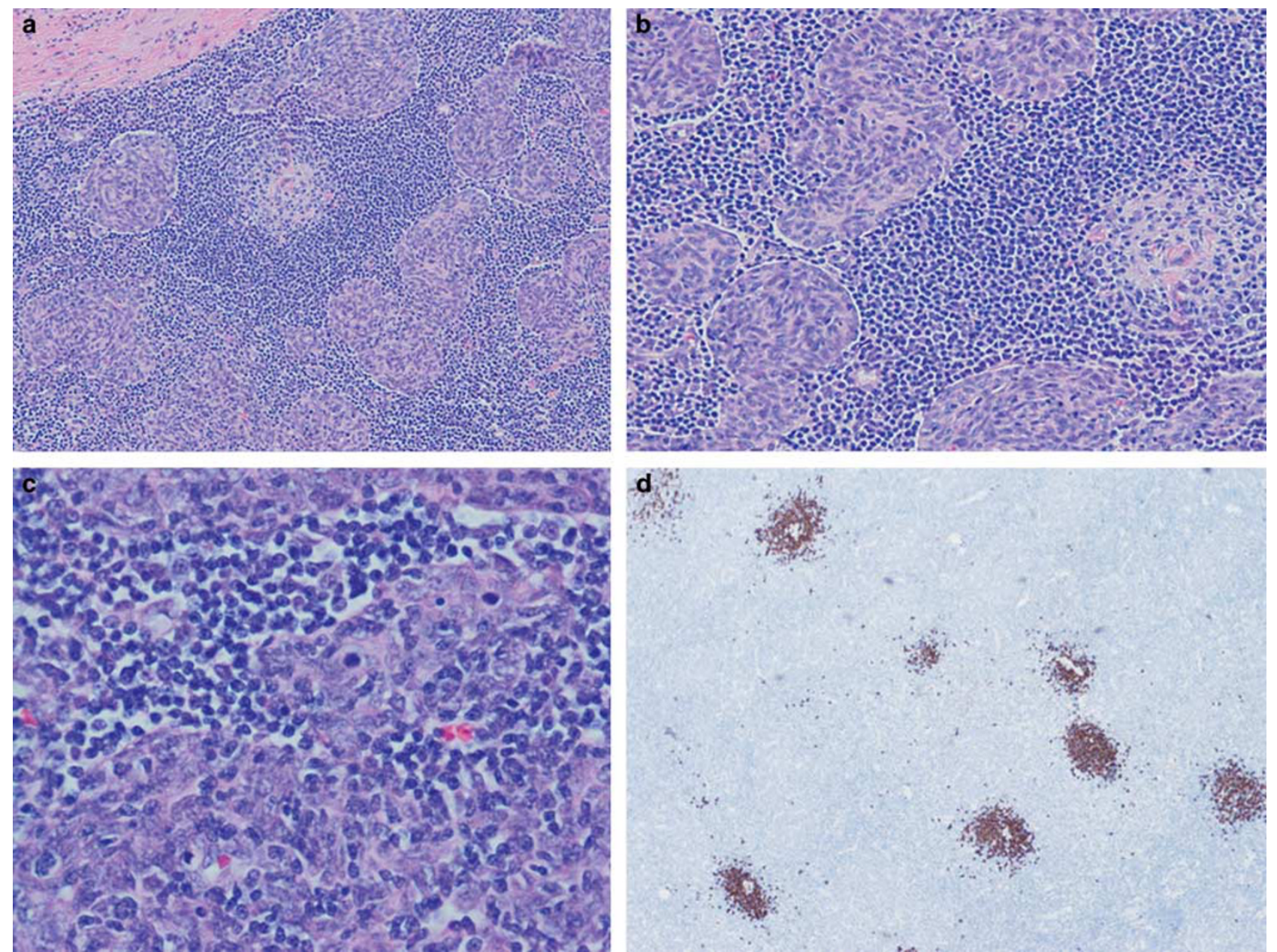

Figure 1 Micronodular thymoma with lymphoid B-cell hyperplasia from the current series: The proliferation shows a micronodular arrangement of the epithelial tumor cells in a lymphoid background with prominent follicular lymphoid hyperplasia (a). Higher power showing the epithelial component consisting of blend spindle cells, admixed with lymphoid follicles showing focal regressive germinal centers (b), as well as scattered mitosis (c). (d) CD20 immunostain highlights the lymphoid follicles.

one case of micronodular thymic carcinoma with lymphoid hyperplasia, showing Castleman diseaselike features.

Treatment consisted mainly of surgical resection. In addition, one micronodular thymoma with lymphoid B-cell hyperplasia case received radiation therapy.

\section{All Cases Combined}

Combining cases of the literature and of the current series revealed 64 cases of micronodular thymoma with lymphoid B-cell hyperplasia and 9 cases of micronodular thymic carcinoma with lymphoid hyperplasia, summarized in Tables 3 and 4, respectively. Both categories showed slight male predilection, with male:female ratio of 1.3:1, including 36 male and 28 female patients for cases of micronodular thymoma with lymphoid B-cell hyperplasia, and 5 male and 4 female patients for cases of micronodular thymic carcinoma with lymphoid hyperplasia; however, the number of cases of micronodular thymic carcinoma with lymphoid hyperplasia seems very limited, precluding definite conclusion. The mean age was 64 years (ranging from 41 to 83) for micronodular thymoma with lymphoid B-cell hyperplasia (15 cases $^{6}$ were reported, combined, between 47 and 79 years with a mean of 63.3), and 62 years (ranging from 42 to 78 ) for micronodular thymic carcinoma with lymphoid hyperplasia.

Myasthenia gravis was noted in 3 of 64 cases (5\%) of micronodular thymoma with lymphoid B-cell hyperplasia and in 1 of 9 cases $(11 \%)$ of micronodular thymic carcinoma with lymphoid hyperplasia. Other systemic, disimmune, or hematologic disorders were noted in 6 of the $64(9 \%)$ patients with micronodular thymoma with lymphoid B-cell hyperplasia, and 1 patient (11\%) with micronodular thymic carcinoma with lymphoid hyperplasia. These conditions included hypogammaglobulinemia, splenomegaly with anemia of undetermined etiology, Sjogren disease, IgA-Lambda paraproteinemia of unknown significance, Protein S deficiency, hypothyroidism, and ulcerative colitis. 

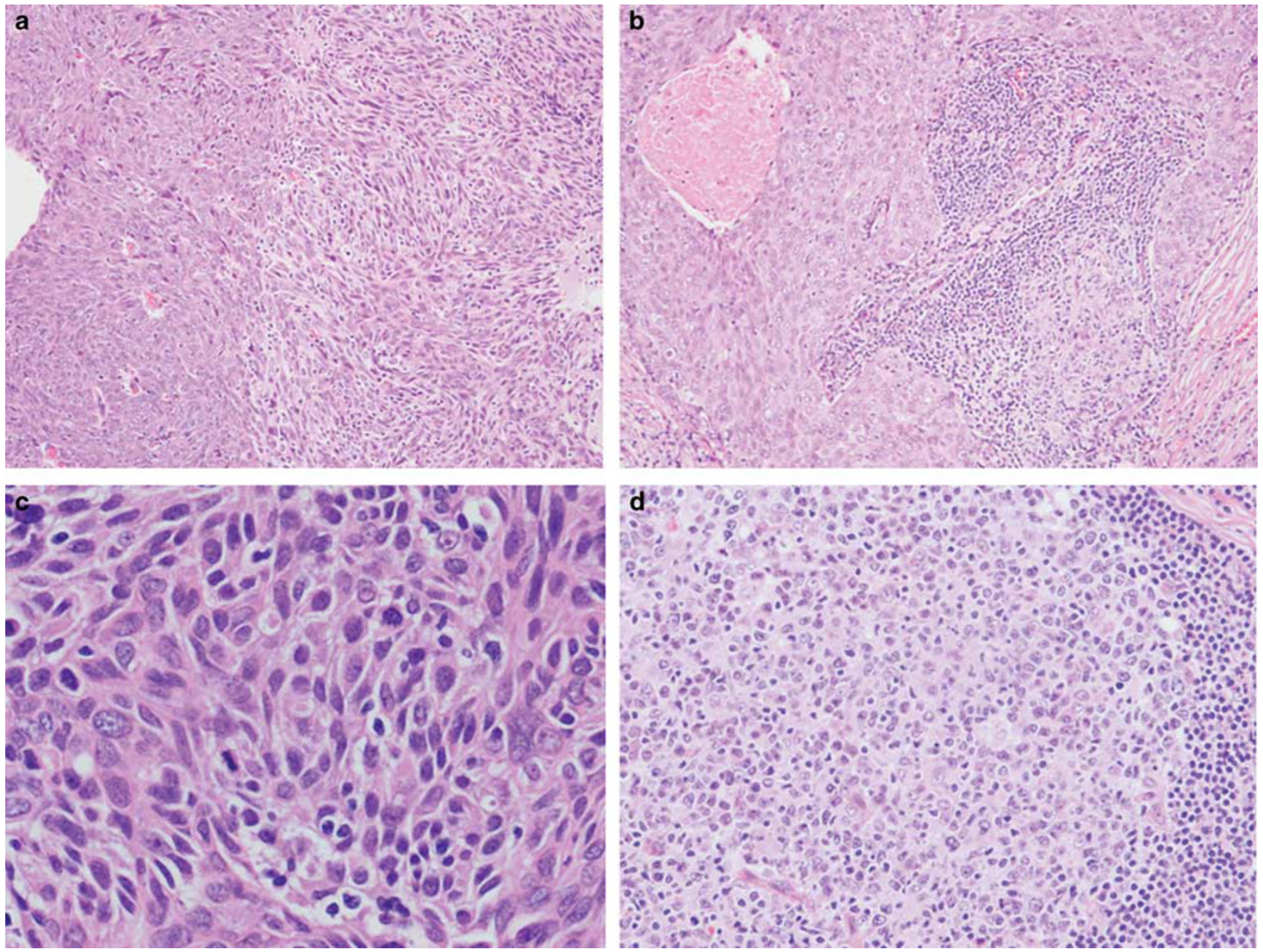

Figure 2 The case of micronodular thymic carcinoma with lymphoid hyperplasia from the current series: (a) Spindle cell (b) and epithelioid carcinoma with focal comedonecrosis. (c) Higher power showing the multiple mitotic figure and cytological atypia. (d) The lymphoid follicles showed germinal centers with progressive transformation in this case.

Conventional thymoma component was seen in 11 of the $64(17 \%)$ cases of micronodular thymoma with lymphoid B-cell hyperplasia, including type A (7 cases), AB (2 cases) AB and B2 (1 case), and B2 (1 case), most of which showing transition between the two components.

Residual thymoma was reported in 15 cases of micronodular thymoma with lymphoid B-cell hyperplasia: 14 of 15 appeared atrophic (with scattered lymphoid follicles in 3 of them; at least two of these three without history of myasthenia gravis) and 1 of 15 revealed lymphoid follicles (patient without myasthenia gravis). Residual thymoma was reported in two cases of micronodular thymic carcinomas with lymphoid hyperplasia, one was atrophic, and the other showed Castleman disease-like features.

Malignancies in other organs were present (synchronous or preceding the thymoma) in 6 of the 64 cases of micronodular thymoma with lymphoid B-cell hyperplasia (9\%), and none of the micronodular thymic carcinomas with lymphoid hyperplasia.

In the micronodular thymoma with lymphoid B-cell hyperplasia group, Masaoka stage was available in 60 of 64 cases, including 33 stage 1, 25 stage 2, one stage 3 , and one stage 4 . In the micronodular thymic carcinoma with lymphoid hyperplasia group, Masaoka stage was available in $8 / 9$ cases, including stage 4 (1 case), stage 3 (3 cases), and stage 1 (4 cases).

Follow-up was available in 30 cases of micronodular thymoma with lymphoid B-cell hyperplasia. The mean follow-up was 47 months (from 0.2 to 180). Five of these patients died from reasons other than the thymoma, and the rest were alive without disease. In addition, 15 cases had disease-free survival between 24 and 190 months (not further detailed).

Micronodular thymic carcinoma with lymphoid hyperplasia follow-up was available in 6 cases with a mean of 23 months (3-39 months), and one of these died of the disease, the rest being alive.

\section{Discussion}

Micronodular thymic tumors with follicular lymphoid hyperplasia seem to show a morphologic spectrum 
Table 2 Literature cases of micronodular thymic neoplasms with follicular lymphoid hyperplasia

Literature cases of MNT, $\mathrm{N}=55$ Literature cases of $M N C A, \mathrm{~N}=8$

Age mean and range (years)
Male:Female
Myasthenia gravis
Autoimmunity state
Size, mean/median/range (cm)
Gross appearance (available for 26 cases of MNT and 7 MNCA)
Solid
Cystic
Mixed
Cell morphology
Spindle
Epithelioid
Mixed
Conventional thymoma component
Present
Transition between micronodular and conventional components
Transition between micronodular and carcinoma
Mitotic count
Necrosis
Low-grade lymphoma
Number of patients with follow-up
Follow-up period in months (mean and range)
Patients dead of disease
Patients dead of other than disease
Masaoka Stage (available for 50 cases of MNT and 7 cases of MNCA)
Stage 1
Stage 2
Stage 3
Stage 4

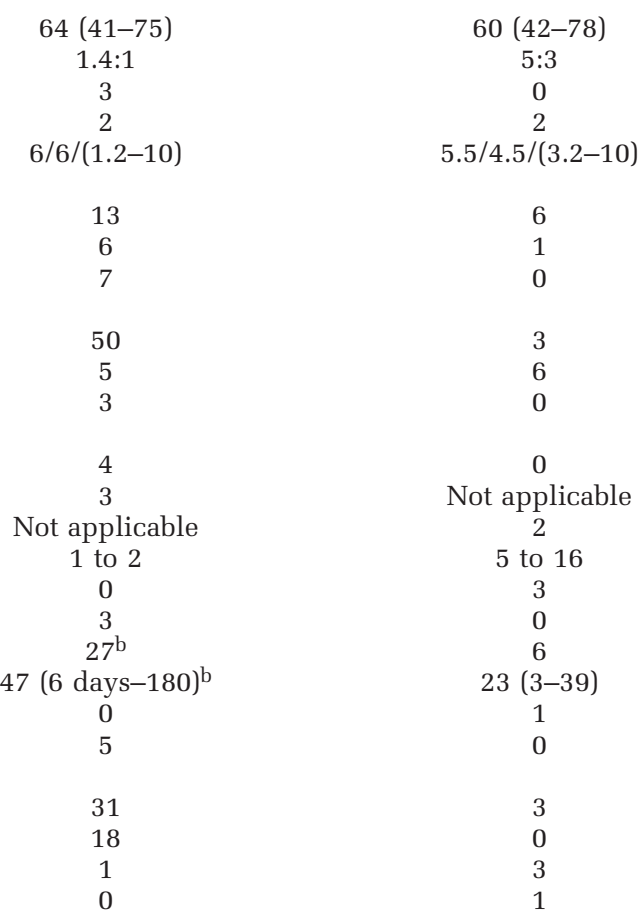

Abbreviations: MNCA, micronodular thymic carcinoma with follicular hyperplasia; MNT, micronodular thymoma with follicular hyperplasia.

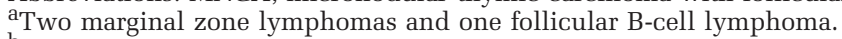

b Additional 15 cases of MNT were followed 24-190 months and were still alive, additional details (mean or median) were not available.

from completely benign micronodular thymoma with lymphoid B-cell hyperplasia to micronodular thymic carcinoma with lymphoid hyperplasia as previously suggested. ${ }^{3}$ It is hypothesized that the follicular lymphoid hyperplasia that is common to all of these tumors is thought to result from the host immune response in reaction to tumor epithelial antigens. ${ }^{2,3,6,10}$ This immune reaction is believed to be beneficial, leading to the overall improved survival in these patients, ${ }^{2,3,6,10}$ such as seen in some other lymphoid-rich neoplasms of both thymic ${ }^{2}$ and nonthymic origin. ${ }^{11-15}$

It is not clear what mechanism initially triggers such immune reaction, or why this type of reaction only occurs in a subset of thymic epithelial neoplasms. In addition, it is not certain whether the mechanism is a localized or more of a systemic process. For instance, the association of myasthenia gravis or other systemic autoimmune diseases with the follicular hyperplasia of thymic tissue is very well established. ${ }^{1,6,16}$ However, most of the patients with micronodular thymic neoplasms with follicular lymphoid hyperplasia do not pertain to this category, since, only in few cases, patients had myasthenia gravis (4 of all cases) or other immunological or systemic disorders (8 of all cases). A recent study that analyzed the distribution of Langerhans and dendritic cells in micronodular thymomas with lymphoid B-cell hyperplasia found that Langerhans cells reside mainly within the epithelial component, and they progressively mature as they migrate towards the lymphoid stroma to become mature interstitial histocytes. ${ }^{10}$ Such findings further supported the theory that the lymphoid hyperplasia reflects a host immune reaction against epithelial tumoral antigens. ${ }^{10}$ Furthermore, 'true' mesenchymal sarcomatous transformation has not been reported in micronodular thymic neoplasms with follicular lymphoid hyperplasia. This is in keeping with the argument that malignant transformation of micronodular thymoma with lymphoid B-cell hyperplasia may be specifically intimately associated with an alteration of this lympho-epithelial interaction, leading either to carcinomas or to lymphomas, but not to true sarcomas.

Another lesion that shares some features with micronodular thymic neoplasms with follicular lymphoid hyperplasia is 'undifferentiated large cell thymic carcinomas with Castleman disease-like change'. ${ }^{17}$ Although these tumors do not display a micronodular appearance, they have like micronodular thymic neoplasms with follicular lymphoid hyperplasia a background of lymphoid follicular hyperplasia. As the name implies, the follicles in 
Table 3 Cases of micronodular thymoma with lymphoid B-cell hyperplasia, including the literature cases and cases from the current series

\begin{tabular}{|c|c|c|c|c|c|c|c|c|c|c|c|c|c|c|c|c|}
\hline $\begin{array}{l}\text { Case } \\
\#\end{array}$ & Age & Sex & Clinical history & Size $(\mathrm{cm})$ & Gross & Stage & Therapy & $\begin{array}{l}\text { Follow- } \\
\text { up }\end{array}$ & $\begin{array}{l}\text { Follow- } \\
\text { up } \\
\text { duration }\end{array}$ & $\begin{array}{l}\text { Epithelial } \\
\text { cells }\end{array}$ & Atypia & $\begin{array}{l}\text { Mitotic } \\
\text { figures }\end{array}$ & $\begin{array}{l}\text { Fibrous } \\
\text { bands }\end{array}$ & $\begin{array}{l}\text { Lymphoid } \\
\text { tissue } \\
\text { specificity }\end{array}$ & Residual thymus & $\begin{array}{l}\text { Conventional } \\
\text { thymoma/ } \\
\text { transition }\end{array}$ \\
\hline \multicolumn{17}{|c|}{ Suster 1999} \\
\hline 1 & 41 & $\mathrm{~F}$ & NS & $8 \times 6.5 \times 5$ & $\mathrm{~s}$ & 1 & $\mathrm{R}$ & NS & LFU & Sp-oval & No & No & NS & NS & NS & NS \\
\hline 2 & 42 & $\mathrm{M}$ & NS & $7 \times 5 \times 3$ & s & 1 & $\mathrm{R}$ & NS & LFU & Sp-oval & No & No & NS & NS & NS & NS \\
\hline 4 & 47 & $\mathrm{M}$ & NS & $9 \times 8 \times 4$ & s & 1 & $\mathrm{R}$ & A & LFU & Sp-oval & No & No & NS & NS & NS & NS \\
\hline 5 & 48 & $\mathrm{~F}$ & NS & $5 \times 5 \times 4$ & $\mathrm{~s}$ & 1 & $\mathrm{R}$ & NS & $2 y$ & Sp-oval & No & No & NS & NS & NS & NS \\
\hline 6 & 48 & $\mathrm{~F}$ & NS & $10 \times 6 \times 5$ & s & 1 & $\mathrm{R}$ & NS & LFU & Sp-oval & No & No & NS & NS & NS & NS \\
\hline 7 & 55 & $\mathrm{M}$ & NS & $8 \times 8 \times 4$ & $\mathrm{~S}$ & 1 & $\mathrm{R}$ & A & LFU & Sp-oval & No & No & NS & NS & NS & NS \\
\hline 8 & 57 & $\mathrm{~F}$ & NS & $6 \times 4 \times 3$ & $S \& C$ & 1 & $\mathrm{R}$ & NS & $3 \mathrm{y}$ & Sp-oval & No & No & NS & NS & NS & NS \\
\hline 9 & 57 & $\mathrm{M}$ & NS & 3 & S & 1 & $\mathrm{R}$ & A & LFU & Sp-oval & No & No & NS & NS & NS & NS \\
\hline 10 & 61 & $\mathrm{~F}$ & NS & $7 \times 5 \times 5$ & $S \& C$ & 1 & $\mathrm{R}$ & A & LFU & Sp—oval & No & No & NS & NS & NS & NS \\
\hline 11 & 62 & $\mathrm{M}$ & NS & $8 \times 7 \times 5$ & S & 2 & $\mathrm{R}$ & A & $7 y$ & Sp-oval & No & No & NS & NS & NS & NS \\
\hline 12 & 63 & $\mathrm{M}$ & NS & $5 \times 4 \times 3$ & $\mathrm{~s}$ & $\begin{array}{l}\text { 4: nodules } \\
\text { in pleura }\end{array}$ & $\begin{array}{l}\text { Not } \\
\text { resectable }\end{array}$ & A & LFU & Sp—oval & No & No & NS & NS & NS & NS \\
\hline 13 & 66 & M & $\begin{array}{l}\text { Melanoma × } 11 \\
\text { years }\end{array}$ & $10 \times 9 \times 8$ & $\begin{array}{l}\text { S \& multi- } \\
\text { C }\end{array}$ & 1 & $\mathrm{R}$ & NS & $1 \mathrm{y}$ & Sp-oval & No & No & NS & NS & NS & NS \\
\hline 14 & 69 & $\mathrm{~F}$ & NS & $5 \times 5 \times 4$ & $\mathrm{~S}$ & 1 & $\mathrm{R}$ & A & $2 \mathrm{y}$ & Sp-oval & No & No & NS & NS & NS & NS \\
\hline 15 & 70 & $\mathrm{~F}$ & Ca of cervix & 4 & C & 1 & $\mathrm{R}$ & & $1 \mathrm{y}$ & Sp—oval & No & No & NS & NS & NS & NS \\
\hline 16 & 70 & $\mathrm{M}$ & SM, AUE & 10 & $S \& C$ & 1 & $\mathrm{R}$ & DNOD & $1 \mathrm{y}$ & Sp-oval & No & No & NS & NS & NS & NS \\
\hline 17 & 72 & $\mathrm{M}$ & NS & 6 & $S \& C$ & 1 & $\mathrm{R}$ & A & LFU & Sp—oval & No & No & NS & NS & NS & NS \\
\hline 18 & 76 & $\mathrm{M}$ & NS & 4 & $S \& C$ & 1 & $\mathrm{R}$ & DNOD & $1 \mathrm{y}$ & $\mathrm{Sp}$-oval & No & No & NS & NS & NS & NS \\
\hline \multicolumn{17}{|c|}{ Tateyama 2000} \\
\hline 1 & 63 & $\mathrm{M}$ & Ca of Esophagus & NS & NS & 2 & $\mathrm{R}$ & DNOD & 11 y $5 \mathrm{mo}$ & & No & 0 & No & NS & NS & No \\
\hline 2 & 71 & $\mathrm{~F}$ & NS & NS & NS & 1 & $\mathrm{R}$ & A & $3 \mathrm{y} 6 \mathrm{mo}$ & $\mathrm{sp}$ & No & 0 & No & NS & NS & No \\
\hline 3 & 61 & $\mathrm{~F}$ & $\begin{array}{l}\text { MG, left eye } \\
\text { ptosis, Rectal Ca }\end{array}$ & NS & NS & 1 & $\mathrm{R}$ & DNOD & $6 \mathrm{y}$ & $\mathrm{Sp}+\mathrm{P}$ & Mild & 0 & No & NS & NS & No \\
\hline 4 & 65 & $\mathrm{~F}$ & NS & NS & NS & 1 & $\mathrm{R}$ & A & 3у $3 \mathrm{mo}$ & $\mathrm{Sp}+\mathrm{P}$ & Mild & 0 & No & NS & NS & No \\
\hline 5 & 58 & $\mathrm{~F}$ & NS & NS & NS & 1 & $\mathrm{R}$ & A & $\begin{array}{c}14 \text { y } 7 \\
\text { mo }\end{array}$ & $\mathrm{P}$ & $\begin{array}{l}\text { Mild } \\
\text {-Mod }\end{array}$ & 2 & Focal & NS & NS & No \\
\hline 6 & 73 & $\mathrm{M}$ & NS & NS & NS & 2 & $\mathrm{R}$ & A & 3 y $7 \mathrm{mo}$ & & $\begin{array}{l}\text { Mild } \\
\text {-Mod }\end{array}$ & 2 & Focal & NS & NS & type A/NS \\
\hline 7 & 61 & $\mathrm{M}$ & NS & NS & NS & 3 & $\mathrm{R}$ & A & 1 y $6 \mathrm{mo}$ & & $\begin{array}{l}\text { Mild } \\
\text {-Mod }\end{array}$ & 1 & Focal & NS & NS & No \\
\hline 8 & 71 & $\mathrm{~F}$ & hGG & NS & NS & 1 & $\mathrm{R}$ & A & $15 \mathrm{y}$ & $\mathrm{P}$ & $\begin{array}{l}\text { Mild } \\
\text {-Mod }\end{array}$ & 1 & Focal & NS & NS & No \\
\hline 9 & 72 & M & NS & NS & NS & 1 & $\mathrm{R}$ & A & 3 y 6 mo & & $\begin{array}{l}\text { Mild } \\
\text {-Mod }\end{array}$ & 1 & Focal & NS & NS & No \\
\hline \multicolumn{17}{|c|}{ De Monpreville 2001} \\
\hline 1 & 47 & $\mathrm{M}$ & COPD & 6 & C & 1 & $\mathrm{R}$ & A & $10.5 \mathrm{y}$ & ov & No & No & NS & NS & \multirow[t]{6}{*}{$\begin{array}{l}\text { Atrophic in all, + lymphoid } \\
\text { follicles in } 2 \text { cases \& multi- } \\
\text { locular cysts in } 2 \text { cases }\end{array}$} & \multirow[t]{6}{*}{$\begin{array}{l}\text { In } 2 \text { cases: type A } \\
\text { nodules; in one case } \\
\text { type B2/Yes }\end{array}$} \\
\hline 2 & 73 & $\mathrm{~F}$ & $\begin{array}{l}\text { MG, breast Ca } \\
\text { radiation x } 30 \\
\text { years }\end{array}$ & 4 & S & $2 b$ & $\mathrm{R}$ & DNOD & $6 \mathrm{~d}$ & oval & No & No & NS & NS & & \\
\hline 3 & 75 & M & COPD & $4 \times 3 \times 2$ & C & $2 b$ & $\mathrm{R}$ & A & $4 \mathrm{y}$ & oval & No & No & NS & NS & & \\
\hline 4 & 59 & $\mathrm{M}$ & sinusitis & $8 \times 6 \times 3.5$ & $\mathrm{~s}$ & $2 \mathrm{~b}$ & $\mathrm{R}, \mathrm{Rad}$ & A & $3 \mathrm{y}$ & oval & No & No & NS & NS & & \\
\hline 5 & 69 & $\mathrm{~F}$ & asthma & $4 \times 4 \times 2$ & $\mathrm{C}$ & $2 \mathrm{~b}$ & $\mathrm{R}$ & Recent & Recent & oval & No & No & NS & NS & & \\
\hline 6 & 70 & $\mathrm{M}$ & COPD & $8 \times 7 \times 4.5$ & Micro-C & $2 \mathrm{a}$ & $\mathrm{R}$ & Recent & Recent & oval & No & No & NS & NS & & \\
\hline \multicolumn{17}{|c|}{ Mende 2004} \\
\hline & 45 & $\mathrm{M}$ & nearing loss & 3.5 & $\begin{array}{l}\text { Micro-L } \\
\text { Ectopic }\end{array}$ & 1 & $\mathrm{~K}$ & A & $12 \mathrm{mo}$ & oval & No & No & NS & NS & NS & NS \\
\hline
\end{tabular}




\begin{tabular}{|c|c|c|c|c|c|c|c|c|c|c|c|c|c|c|c|c|}
\hline $\begin{array}{l}\text { Case } \\
\#\end{array}$ & Age & Sex & Clinical history & Size $(\mathrm{cm})$ & Gross & Stage & Therapy & $\begin{array}{l}\text { Follow- } \\
\text { up }\end{array}$ & $\begin{array}{l}\text { Follow- } \\
\text { up } \\
\text { duration }\end{array}$ & $\begin{array}{l}\text { Epithelial } \\
\text { cells }\end{array}$ & Atypia & $\begin{array}{l}\text { Mitotic } \\
\text { figures }\end{array}$ & $\begin{array}{l}\text { Fibrous } \\
\text { bands }\end{array}$ & $\begin{array}{l}\text { Lymphoid } \\
\text { tissue } \\
\text { specificity }\end{array}$ & Residual thymus & $\begin{array}{l}\text { Conventional } \\
\text { thymoma/ } \\
\text { transition }\end{array}$ \\
\hline \multicolumn{17}{|c|}{ Strobel 2005} \\
\hline $15^{1-}$ & $\begin{array}{l}47- \\
79\end{array}$ & $\begin{array}{l}8 \mathrm{M} \\
7 \mathrm{~F}\end{array}$ & MG in 1 case & NS & NS & $\begin{array}{l}\text { stage } 1 \text { in } 5 ; \\
\text { stage } 2 \text { in } 7 ; \\
\quad \text { NS in } 3\end{array}$ & $\mathrm{R}$ & A & $24-190$ & Sp & No & No & NS & $\begin{array}{l}\text { In 13-15: } \\
\text { monoclonal Ig } \\
\text { rearrangement }\end{array}$ & NS & NS \\
\hline 16 & 68 & M & & & & 2 & & A & 24 & Sp & No & No & NS & $\begin{array}{l}\text { MZL; LEL in } \\
\text { cyst lining }\end{array}$ & NS & NS \\
\hline 17 & 69 & M & & & & 2 & & NA & NA & Sp & No & No & NS & $\begin{array}{l}\text { MZL; LEL in } \\
\text { cyst lining }\end{array}$ & NS & NS \\
\hline 18 & 72 & $\mathrm{M}$ & & & & 2 & & A & 24 & Sp & No & No & NS & $\begin{array}{l}\text { FL-LG; LEL in } \\
\text { cyst lining }\end{array}$ & NS & NS \\
\hline \multicolumn{17}{|c|}{ Mourra 2005} \\
\hline \multirow{2}{*}{\multicolumn{17}{|c|}{ El Mezni 2006}} \\
\hline & & & & & & & & & & & & & & & & \\
\hline 1 & 62 & $\mathrm{~F}$ & NS & $8 \times 6 \times 6$ & $\mathrm{~s}$ & 2 & $\mathrm{R}$ & A & $2 \mathrm{y}$ & $\mathrm{Sp}-\mathrm{oval}$ & No & No & NS & NS & NS & NS \\
\hline 2 & 64 & $\mathrm{M}$ & NS & $7 \times 5 \times 2$ & $S \& C$ & 1 & $\mathrm{R}$ & A & $17 \mathrm{mo}$ & Sp-oval & No & No & NS & NS & With LF & NS \\
\hline \multicolumn{17}{|c|}{ Kim 2013} \\
\hline & 73 & $\mathrm{M}$ & NS & 5.1 & $\begin{array}{l}\text { In multi- } \\
\text { locular } \\
\text { thymic } \\
\text { cyst }\end{array}$ & 1 & $\mathrm{R}$ & A & $12 \mathrm{mo}$ & $\begin{array}{l}\text { Sp round } \\
\text { plump }\end{array}$ & No & No & $\begin{array}{l}\text { Focal in I } \\
\text { cyst } \\
\text { walls }\end{array}$ & & NS & NS \\
\hline \multicolumn{17}{|c|}{ Current cases } \\
\hline & 79 & $\mathrm{~F}$ & NS & U & $S \& C$ & 1 & $\mathrm{R}$ & NS & NS & $\begin{array}{l}\text { Sp, rare } \\
\text { Ep }\end{array}$ & No & 2 to 8 & No & Some atrophic & Atrophic & $\begin{array}{l}1 \mathrm{~cm} \text { type } \mathrm{A} \\
\text { thymoma/Yes }\end{array}$ \\
\hline & 83 & M & NS & $\begin{array}{l}8.5 \times 7 \times 4 \\
\text { MNT: } 30 \%\end{array}$ & $\begin{array}{l}\text { S, rare } \\
\text { micro-c }\end{array}$ & 1 & $\mathrm{R}$ & NS & NS & $\mathrm{Ep}>\mathrm{Sp}$ & Mild & 3 & Yes & NS & Atrophic with LF & $\mathrm{AB} \& \mathrm{~B} 2 / \mathrm{Yes}$ \\
\hline & 70 & $\mathrm{M}$ & NS & 5.9 & $\mathrm{~s}$ & $2 \mathrm{a}$ & $\mathrm{R}$ & NS & NS & Ep & Mild & 11 & Yes & NS & Atrophic & $\begin{array}{l}\text { Epithelioid } \\
\text { A/Yes }\end{array}$ \\
\hline & 64 & $\mathrm{~F}$ & $\begin{array}{l}\text { hThyr, osteop, } \\
\text { right facial } \\
\text { paralysis }\end{array}$ & $6 \times 6 \times 6$ & S & $2 b$ & $\mathrm{R}$ & NS & NS & Sp & No & 1 & Focal I & NS & Atrophic & $\begin{array}{l}0.5 \mathrm{~cm} \text { nodules } \\
\text { of cellular A/Yes }\end{array}$ \\
\hline & 61 & $\mathrm{~F}$ & NS & $3 \times 2.5 \times 2$ & $\begin{array}{l}\text { S, rare } \\
\text { micro-C }\end{array}$ & $2 \mathrm{a}$ & $\mathrm{R}$ & NS & NS & Sp \& Ep & No & 2 & Yes & NS & Atrophic & $\begin{array}{l}\mathrm{AB} / \text { Yes \& Sclerosed } \\
\text { ancient thymoma }\end{array}$ \\
\hline & 73 & F & $\begin{array}{l}\text { MGUS IgA lambda } \\
\text { persisted after R, } \\
\text { lytic lesion of } \\
\text { skull }\end{array}$ & $\begin{array}{l}4.5 \times 4.4 \times 3 \\
\text { MNT: } 40 \%\end{array}$ & $\begin{array}{l}\text { S, rare } \\
\text { micro-C }\end{array}$ & $2 a$ & $\mathrm{R}$ & A & $6 y$ & Sp \& Ep & No & 2 & No & NS & Atrophic & $\mathrm{AB}$ \\
\hline & 63 & $\mathrm{M}$ & Lung Adeno & $5.5 \times 4 \times 1.5$ & $\mathrm{~S}$, rare C & $2 \mathrm{a}$ & $\begin{array}{l}\text { R Chem } \\
\text { for lung } \\
\mathrm{Ca}\end{array}$ & A & $3 y$ & $\mathrm{Ep}>\mathrm{Sp}$ & Mild & 5 & Focal & NS & Atrophic & A2 \\
\hline & 51 & M & $\begin{array}{l}\text { HTN, DM2, Prot S } \\
\text { deficit, impaired } \\
\text { vision }\end{array}$ & $4.8 \times 2.7$ & $S \& C$ & $2 a$ & $\mathrm{R}$ & A & Recent & Sp \& Ep & Mild & 5 & No & Some atrophic & Atrophic & No \\
\hline & 53 & F & UC & $3 \times 2.8 \times 1.5$ & S, rare C & $2 a$ & $\mathrm{R}$ & A & $3 y$ & $\begin{array}{l}\text { Sp, rare } \\
\text { Ep }\end{array}$ & No & 1 & Focal & Some atrophic & Atrophic & No \\
\hline
\end{tabular}

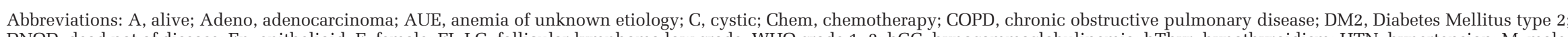
DNOD, dead not of disease; Ep, epithelioid; F, female; FL-LG, follicular lymphoma low grade, WHO grade 1-2; hGG, hypogammaglobulinemia; hThyr, hypothyroidism; HTN, hypertension; M, male;

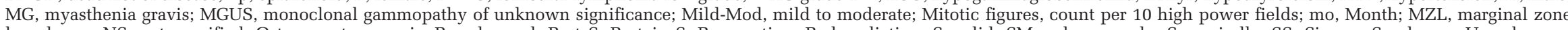

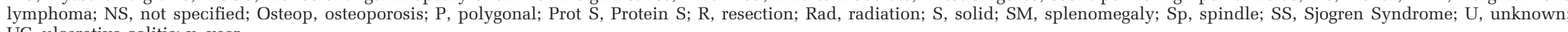
UC, ulcerative colitis; y, year. 
Table 4 Cases of micronodular thymic carcinoma with lymphoid hyperplasia, including literature cases and the case from the current series

\begin{tabular}{|c|c|c|c|c|c|c|c|c|c|c|c|c|c|c|c|c|c|}
\hline Case \# & $\begin{array}{l}\text { Age } \\
\text { in } \\
\text { years }\end{array}$ & Sex & $\begin{array}{l}\text { Clinical } \\
\text { history }\end{array}$ & Size $(\mathrm{cm})$ & Gross & Stage & Therapy & Follow-up & $\begin{array}{l}\text { Follow- } \\
\text { up } \\
\text { duration }\end{array}$ & $\begin{array}{l}\text { Epithelial } \\
\text { cells }\end{array}$ & $\begin{array}{l}\text { Mitotic } \\
\text { figures }\end{array}$ & Necrosis & $\begin{array}{l}\text { Fibrous } \\
\text { bands }\end{array}$ & $\begin{array}{l}\text { Adjacent } \\
\text { thymus }\end{array}$ & $\begin{array}{l}\text { Lymphoid } \\
\text { component }\end{array}$ & $\mathrm{Ca}$ & $\begin{array}{l}\text { Transition } \\
\text { to } \mathrm{Ca}\end{array}$ \\
\hline \multicolumn{18}{|c|}{ Suster 1999} \\
\hline 3 & 45 & M & $\begin{array}{l}\text { Cavitary } \\
\text { TB }\end{array}$ & $4 \times 4 \times 2$ & $\mathrm{C}$ & NS & & NS & LFU & Sp & NS & $\begin{array}{l}\text { Comedo } \\
\text { type }\end{array}$ & NS & $\begin{array}{l}\text { Focal CD } \\
\text { like } \\
\text { change }\end{array}$ & NS & $\begin{array}{c}\text { LEO Ca } \\
\& \text { PD } \\
\text { SqCC }\end{array}$ & Yes \\
\hline \multicolumn{18}{|c|}{ Tateyama 2000} \\
\hline 10 & 56 & $\mathrm{~F}$ & SS, hGG & NS & NS & 3 & $\mathrm{R}$ & LFU & LFU & Ep & 5 & No & Yes & NS & NS & $\begin{array}{l}\text { LEO like } \\
\text { Ca }\end{array}$ & No \\
\hline 11 & 59 & M & NS & NS & NS & $4 a$ & $\mathrm{R}$ & A & $39 \mathrm{mo}$ & Ep & 6 & No & Yes & NS & NS & $\begin{array}{l}\text { LEO Ca } \\
\text { \& SqCC }\end{array}$ & No \\
\hline \multicolumn{18}{|c|}{ Weissferdt 2012} \\
\hline 1 & 61 & $\mathrm{~F}$ & NS & 5 & $\mathrm{~S}$ & $\begin{array}{c}\text { Stage } \\
1 \text { in } 3 ; \\
\text { Stage } \\
3 \text { in } 2\end{array}$ & $\mathrm{R}$ & A & $3 \mathrm{mo}$ & $\begin{array}{l}\text { In } 3 \text { cases: } \\
\text { large } \\
\text { round- } \\
\text { oval, } \\
\text { vesicular } \\
\text { nuclei; } \\
\text { spindle } \\
\text { cells in the } \\
\text { rest }\end{array}$ & 5 to 16 & $\begin{array}{l}\text { Yes, in } 2 \\
\text { cases }\end{array}$ & NS & NS & $\begin{array}{l}\text { In } 1 \text { case, } \\
\text { hyalinized } \\
\text { centers of } \\
\text { lymphoid } \\
\text { follicles }\end{array}$ & $\begin{array}{l}2 \text { cases: } \\
\text { spindle } \\
\text { cell Ca; } 3 \\
\text { cases: of } \\
\text { SqCC }\end{array}$ & In one case \\
\hline 2 & 78 & $\mathrm{M}$ & NS & 3.2 & $\mathrm{~S}$ & & $\mathrm{R}$ & A & $26 \mathrm{mo}$ & & & & & & & & \\
\hline 3 & 71 & $\mathrm{M}$ & NS & 10 & $\mathrm{~S}$ & & $\mathrm{R}$ & A & $26 \mathrm{mo}$ & & & & & & & & \\
\hline 4 & 67 & $\mathrm{~F}$ & NS & NS & $\mathrm{S}$ & & $\mathrm{R}$ & DOD & $21 \mathrm{mo}$ & & & & & & & & \\
\hline 5 & 42 & $\mathrm{M}$ & NS & NS & $\mathrm{S}$ & & $\mathrm{R}$ & A & $24 \mathrm{mo}$ & & & & & & & & \\
\hline \multicolumn{18}{|c|}{ Current case } \\
\hline 10 & 75 & $\mathrm{~F}$ & MG & 2.7 & $\mathrm{~S}$ & 1 & $\mathrm{R}$, Rad & & NS & Ep & $\begin{array}{c}3 \text { to } 8 \text { in } \\
\text { Ca }\end{array}$ & $\begin{array}{l}\text { Comedo } \\
\text { type }\end{array}$ & Yes & $\begin{array}{l}\text { atrophic } \\
\text { with LF }\end{array}$ & $\begin{array}{l}\text { PTGC } \\
\text { features }\end{array}$ & $\begin{array}{l}\text { LEO Ca } \\
\& \text { SpCC }\end{array}$ & Yes \\
\hline
\end{tabular}

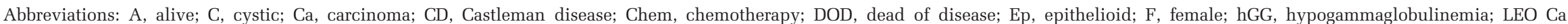

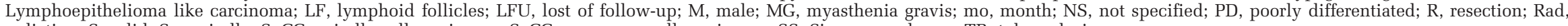
radiation; S, solid; Sp, spindle; SpCC, spindle cell carcinoma; SqCC, squamous cell carcinoma; SS, Sjogren syndrome; TB, tuberculosis; y, year. 
undifferentiated large cell thymic carcinomas with Castleman disease-like change likely have morphology reminiscent to Castleman disease. The carcinomatous component in these cases consists of a lymphoepithelioma-like carcinoma, with peculiar tendency of the tumor nests to be located in the center of the follicles. Surprisingly, the few cases of undifferentiated large cell thymic carcinomas with Castleman disease-like change described to date have behaved in an indolent manner despite the high-grade morphology in these tumors, and despite the presence of lymph-node metastasis in one of the cases. ${ }^{17}$

The continuous spectrum between spindle and epithelioid morphology with intermediate morphologic states suggests that these two cell types are the two extreme morphologic states of the same neoplastic thymocyte, and that the distinction between type A (medullary) and type B (cortical) cells is arbitrary. This is also supported by the fact that type $A$ and $B$ cells have overlapping immunophenotypes that do not recapitulate the phylogenetic characteristics of cortical and medullary cells present in normal thymus. ${ }^{18,19}$ In addition, a previous gene expression clustering analysis and genomic profiling study revealed that type $\mathrm{A}$ and type $\mathrm{B}$ thymomas did not always show differential distinct profiles, ${ }^{20}$ and another genomic profiling study showed revealed distinct differences only between type $\mathrm{A}$ to B2 thymomas versus type B3 and thymic carcinomas. ${ }^{21}$ It should be noted that these findings were not confirmed in all studies; for instance, one study described distinct groups of $\mathrm{A}, \mathrm{AB}, \mathrm{B} 1+2$, and $\mathrm{B}^{22}$ by comparative genome hybridization.

Transitional morphology between the low-grade micronodular and the carcinomatous component was noted in cases of micronodular thymic carcinoma with lymphoid hyperplasia, which supports the possibility of a dedifferentiation or transformation process, rather than de novo development leading to thymic carcinomas. This is an alternative pathway of malignant transformation in addition to the progression pathway from spindle to epithelioid morphology reported by Tateyama et al. ${ }^{3}$

The presence of conventional component in the micronodular thymoma with lymphoid B-cell hyperplasia has been previously mentioned in few cases in the literature ${ }^{1-3}$ as well as in several of our cases (11 of the total 64 cases of micronodular thymoma with lymphoid B-cell hyperplasia, 17\%). Transition between the conventional and the micronodular components was noted in some of these. Other similarities exist between micronodular and conventional thymic neoplasms. After literature review, it is our impression that conventional and the micronodular thymic neoplasms share common morphologic characteristics associated with higher grade or end spectrum of differentiation. For instance, epithelioid cell predominance with confluent sheets is seen also in conventional type B3 thymoma. Furthermore, it has been recently suggested that $A B$ thymomas that have epithelioid cellular morphology (among other features) may be associated with higher risk of recurrence. ${ }^{23}$ Cytological atypia, although somehow subjective, is noted to increase in micronodular thymomas with lymphoid B-cell hyperplasia along the progression toward epithelioid morphology and carcinomas, which is similar to atypical type A thymoma that tends to behave more aggressively. ${ }^{23-27}$ Overt malignant morphology is diagnostic of carcinoma in both micronodular and conventional categories, and, like the spindle micronodular neoplasm with transitional morphology to carcinoma, a transition between type A thymomas and lymphoepithelioma-like thymic carcinoma ${ }^{23}$ or spindle cell 'sarcomatoid' carcinoma ${ }^{23,25}$ has been well documented. These similarities are based on pure morphological features, and do not imply in any mean that the pathophysiology is necessarily similar in both micronodular and conventional thymic neoplasms.

The malignant transformation may affect also the lymphoid component of micronodular thymoma with lymphoid B-cell hyperplasia: In fact, Strobel et $a l^{6}$ have investigated the incidence of lymphoproliferations in two groups of patients presenting with thymic neoplasms: the group of micronodular thymomas with lymphoid B-cell hyperplasia and that of conventional thymomas. These authors examined expression of several cytokines by immunohistochemistry, the detection of monoclonal lymphoid population, the detection of translocation $t(14,18)$, and the repartition of interstitial dendritic cells and macrophages. In their study, the authors diagnosed extranodal marginal cell lymphoma in 2 of the 18 cases of micronodular thymoma with lymphoid B-cell hyperplasia, and a follicular lymphoma WHO grade 1-2, in one case. Moreover, monoclonal immunoglobulin rearrangement was identified in three other micronodular thymomas with lymphoid B-cell hyperplasia cases. In contrast, no lymphoma or monoclonal immunoglobulin rearrangement was detected in any of the cases of conventional thymomas. These observations suggest that the progression to lymphoma secondarily to a clonal selection in long-term antigenic stimulation states is also valid in micronodular thymic neoplasms with follicular lymphoid hyperplasia of the thymus. ${ }^{6}$ It is not clear why lymphomas were found in this specific series and not in others. One possibility is that low-grade lymphomatous transformation has been overlooked in the cases of micronodular thymic neoplasms with follicular lymphoid hyperplasia. In our current series, no lymphoma was diagnosed, but one of our cases revealed for instance enlarged lymphoid follicles with progressive transformation of germinal center appearance, which is known to be associated with lymphoid predominance nodular Hodgkin lymphoma. ${ }^{16,28}$

A recent study of gene expression on thymoma showed that the outcome of thymomas may be predicted according to nine genes expression, where 
high level of expression is associated with a more adverse prognosis ( $>85 \%$ of chance of recurrence or metastasis, as compared with $<15 \%$ of chance of recurrence or metastasis for the group with low expression). This test was performed on only one of our cases of micronodular thymomas with lymphoid B-cell hyperplasia (case \#10), which was classified in the good prognosis category. It would be very interesting to test all micronodular thymic neoplasms with follicular lymphoid hyperplasia and see if they are could be segregated according to the gene expression profile similarly to the conventional thymoma group. However, this would require large numbers of cases with good follow-up.

In conclusion, micronodular thymoma with lymphoid B-cell hyperplasia and micronodular thymic carcinoma with lymphoid hyperplasia are rare tumors that occur manly in patients $>40$ years of age, with slight male predominance. A small subset may occur in patients with disimmune disorders including myasthenia gravis. Not infrequently, components of conventional thymoma of various types may be admixed with the micronodular thymic neoplasms with follicular lymphoid hyperplasia, sometimes with transitional morphology between the two components. Similarly to conventional thymomas, the diffuse epithelioid morphology, the overt cytological atypia, and the frank carcinomatous component are at the end of the spectrum of differentiation. Dedifferentiation or transformation from micronodular thymoma with lymphoid B-cell hyperplasia to micronodular thymic carcinoma with lymphoid hyperplasia seems to occur in a small subset of cases, and rare cases of low-grade B-cell lymphomas developed in micronodular thymoma with lymphoid B-cell hyperplasia were reported.

\section{Disclosure/conflict of interest}

The authors declare no conflict of interest.

\section{References}

1 Suster S, Moran CA. Micronodular thymoma with lymphoid B-cell hyperplasia: clinicopathologic and immunohistochemical study of eighteen cases of a distinctive morphologic variant of thymic epithelial neoplasm. Am J Surg Pathol 1999;23:955-962.

2 Weissferdt A, Moran CA. Micronodular thymic carcinoma with lymphoid hyperplasia: a clinicopathological and immunohistochemical study of five cases. Mod Pathol 2012;25:993-999.

3 Tateyama H, Saito Y, Fujii Y et al. The spectrum of micronodular thymic epithelial tumours with lymphoid B-cell hyperplasia. Histopathology 2001;38: 519-527.

4 Thomas De Montpréville V, Zemoura L, Dulmet E. Thymoma with epithelial micronodules and lymphoid hyperplasia: six cases of a rare and equivocal subtype. Ann Pathol 2002;22:177-182.
5 Mende S, Moschopulos M, Marx A et al. Ectopic micronodular thymoma with lymphoid stroma. Virchows Arch 2004;444:397-399.

6 Ströbel P, Marino M, Feuchtenberger M et al. Micronodular thymoma: an epithelial tumour with abnormal chemokine expression setting the stage for lymphoma development. J Pathol207:72-82.

7 Mourra N, Duron F, Parc R et al. Cervical ectopic thymoma: a diagnostic pitfall on frozen section. Histopathology 2005;46:583-585.

8 El MF, Braham E, Ayadi A et al. Micronodular thymoma with lymphoid stroma: report of two cases and particular association with thymic lymphoid hyperplasia in one case. Pathology 2006;38: 586-588.

9 Lee NR, Ha JI, Micronodular SY. Thymoma with lymphoid stroma in a multilocular thymic cyst: a case study. Korean J Pathol 2013;47:392-394.

10 Ishikawa Y, Tateyama $\mathrm{H}$, Yoshida $\mathrm{M}$ et al. Micronodular thymoma with lymphoid stroma: an immunohistochemical study of the distribution of langerhans cells and mature dendritic cells in six patients. Histopathology 2014;66:300-307.

11 Adams S, Gray RJ, Demaria S et al. Prognostic value of tumor-infiltrating lymphocytes in triple-negative breast cancers from two phase III randomized adjuvant breast cancer trials: ECOG 2197 and ECOG 1199. J Clin Oncol 2014 20;32:2959-2966.

12 Loi S, Sirtaine N, Piette F et al. Prognostic and predictive value of tumor-infiltrating lymphocytes in a phase III randomized adjuvant breast cancer trial in node-positive breast cancer comparing the addition of docetaxel to doxorubicin with doxorubicin-based chemotherapy: BIG 02-98. J Clin Oncol 2013;31: 860-867.

13 Dudley ME, Gross CA, Somerville RPT et al. Randomized selection design trial evaluating cd8+-enriched versus unselected tumor-infiltrating lymphocytes for adoptive cell therapy for patients with melanoma. J Clin Oncol 2013;10:2152-2159.

14 Loi S, Michiels S, Salgado R et al. Tumor infiltrating lymphocytes are prognostic in triple negative breast cancer and predictive for trastuzumabbenefit in early breast cancer: results from the FinHER trial. Ann Oncol 2014;25:1544-1550.

15 Thomas NE, Busam KJ, From L et al. Tumor-infiltrating lymphocyte grade in primary melanomas is independently associated with melanoma-specific survival in the population-based genes, environment and melanoma study. J Clin Oncol 2013;31:4252-4259.

16 Burns BF, Colby TV, Dorfman RF. Differential diagnostic features of nodular L \& H Hodgkin's disease, including progressive transformation of germinal centers. Am J Surg Pathol 1984;8:253-261.

17 Nonaka D, Rodriguez J, Rollo JL et al. Undifferentiated large cell carcinoma of the thymus associated with Castleman disease-like reaction: a distinctive type of thymic neoplasm characterized by an indolent behavior. Am J Surg Pathol 2005;29:490-495.

18 Giraud F, Fabien N, Auger C et al. Human epithelial thymic tumours: heterogeneity in immunostaining of epithelial cell markers and thymic hormones. Thymus 1990;15:15-29.

19 Kraus VB, Harden EA, Wittels B et al. Demonstration of phenotypic abnormalities of thymic epithelium in thymoma including two cases with abundant Langerhans cells. Am J Pathol 1988;132:552-562. 
20 Girard N, Shen R, Guo T et al. Comprehensive genomic analysis reveals clinically relevant molecular distinctions between thymic carcinomas and thymomas. Clin Cancer Res 2009;15:6790-6799.

21 Badve S, Goswami C, Gökmen-Polar Y et al. Molecular analysis of thymoma. PLoS One 2012;7:e42669.

22 Lee GY, Yang WI, Jeung HC et al. Genome-wide genetic aberrations of thymoma using cDNA microarray based comparative genomic hybridization. BMC Genomics 2007;8:305.

23 Moran CA, Kalhor N, Suster S. Invasive spindle cell thymomas (WHO Type A): a clinicopathologic correlation of 41 cases. Am J Clin Pathol 2010;134:793-798.

24 Jain RK, Mehta RJ, Henley JD et al. WHO types A and AB thymomas: not always benign. Mod Pathol 2010;23: 1641-1649.
25 Nonaka D, Rosai J. Is there a spectrum of cytologic atypia in type a thymomas analogous to that seen in type B thymomas? A pilot study of 13 cases. Am J Surg Pathol 2012;36:889-894.

26 Vladislav IT, Gökmen-Polar Y, Kesler KA et al. The prognostic value of architectural patterns in a study of 37 type AB thymomas. Mod Pathol 2014;27: 863-868.

27 Vladislav IT, Gökmen-Polar Y, Kesler KA et al. The role of histology in predicting recurrence of type A thymomas: a clinicopathologic correlation of 23 cases. Mod Pathol 2013;26:1059-1064.

28 Miles RR, Cairo MS. A pediatric translational perspective on the entity "progressive transformation of germinal centers (PTGC)". Pediatr Blood Cancer 2013;60:3-4. 